University of Nebraska - Lincoln

DigitalCommons@University of Nebraska - Lincoln

2012

\title{
Mapping Anuran Habitat Suitability to Estimate Effects of Grassland and Wetland Conservation Programs
}

David M. Mushet

U.S. Geological Survey, dmushet@usgs.gov

Ned H. Euliss Jr.

U.S. Geological Survey, ceuliss@usgs.gov

Craig A. Stockwell

North Dakota State University - Main Campus, craig.stockwell@ndsu.edu

Follow this and additional works at: https://digitalcommons.unl.edu/usgsnpwrc

Mushet, David M.; Euliss, Ned H. Jr.; and Stockwell, Craig A., "Mapping Anuran Habitat Suitability to Estimate Effects of Grassland and Wetland Conservation Programs" (2012). USGS Northern Prairie Wildlife Research Center. 279.

https://digitalcommons.unl.edu/usgsnpwrc/279

This Article is brought to you for free and open access by the US Geological Survey at DigitalCommons@University of Nebraska - Lincoln. It has been accepted for inclusion in USGS Northern Prairie Wildlife Research Center by an authorized administrator of DigitalCommons@University of Nebraska - Lincoln. 


\title{
Mapping Anuran Habitat Suitability to Estimate Effects of Grassland and Wetland Conservation Programs
}

\author{
David M. Mushet ${ }^{1,2}$, Ned H. Euliss, Jr. ${ }^{1}$, and Craig A. Stockwell ${ }^{2}$
}

\begin{abstract}
The conversion of the Northern Great Plains of North America to a landscape favoring agricultural commodity production has negatively impacted wildlife habitats. To offset impacts, conservation programs have been implemented by the U.S. Department of Agriculture and other agencies to restore grassland and wetland habitat components. To evaluate effects of these efforts on anuran habitats, we used call survey data and environmental data in ecological niche factor analyses implemented through the program Biomapper to quantify habitat suitability for five anuran species within a $196 \mathbf{~ k m}^{2}$ study area. Our amphibian call surveys identified Northern Leopard Frogs (Lithobates pipiens), Wood Frogs (Lithobates sylvaticus), Boreal Chorus Frogs (Pseudacris maculata), Great Plains Toads (Anaxyrus cognatus), and Woodhouse's Toads (Anaxyrus woodhousii) occurring within the study area. Habitat suitability maps developed for each species revealed differing patterns of suitable habitat among species. The most significant findings of our mapping effort were 1) the influence of deep-water overwintering wetlands on suitable habitat for all species encountered except the Boreal Chorus Frog; 2) the lack of overlap between areas of core habitat for both the Northern Leopard Frog and Wood Frog compared to the core habitat for both toad species; and 3) the importance of conservation programs in providing grassland components of Northern Leopard Frog and Wood Frog habitat. The differences in habitats suitable for the five species we studied in the Northern Great Plains, i.e., their ecological niches, highlight the importance of utilizing an ecosystem based approach that considers the varying needs of multiple species in the development of amphibian conservation and management plans.
\end{abstract}

A MPHIBIAN species have been declining worldwide (Wake and Morowitz, 1991) and have often been compared to "canaries in a coal mine" in terms of indicating environmental degradation (e.g., Cowen, 1990; Halliday, 2000; Norris, 2007). However, newer information has shown that many amphibian species are not especially sensitive to various disturbances and pollutants; changes in amphibian populations, instead of being an early warning of potentially negative impacts, may be the result of an already significantly degraded ecosystem (Kerby et al., 2010). The primary human perturbation affecting amphibian populations in the Northern Great Plains (NGP) has been the conversion of natural grasslands and wetlands to cropland (Lannoo et al., 1994; Lannoo, 1998; Larson et al., 1998; Knutson et al., 1999). Amphibian population declines related to land-use change are by no means limited to the NGP and have been implicated as a primary causal factor in the global decline of amphibians (Houlahan et al., 2000; Alford et al., 2001). Although landscape conversion facilitating agricultural production has rewarded the NGP's economy, negative impacts to biotic communities and various ecosystem services also have occurred.

In response to concerns over the loss of ecosystem services, including the loss of amphibian habitats, numerous conservation programs now encourage the return of marginal agricultural croplands back into some form of grassland cover, e.g., Conservation Reserve Program, Wetlands Reserve Program, Partners for Wildlife. However, incentives offered to land owners to remove lands from agricultural production have not kept pace with rising commodity prices. Thus, many conservation programs have become less attractive to landowners resulting in vast areas of conservation grasslands within the NGP being reconverted to agricultural crop production. In 2007 alone, 162,000 ha of Conservation Reserves Program grasslands returned to agricultural crop production in North Dakota. Future grassland losses may mount as contracts on nearly 5.5 million ha expire within the United States between 2012 and 2015 (U.S. Department of Agriculture, 2011). A large majority of these Conservation Reserve Program contracts are in the NGP. If these contracts are not renewed, economic drivers will ensure that most affected lands will be put back into crop production with potential dire consequences for amphibians.

Ecological niche theory (Chase and Leibold, 2003) offers a way of estimating how environmental changes, such as the loss of conservation grasslands affect the suitability of a landscape for a species of interest (Hirzel et al., 2008). Hutchinson's (1957) definition of a niche as an n-dimensional hypervolume of environmental conditions within which a species can exist is "requirement" based (Grinnell, 1917) and as such offers a conceptual mechanism to link the fitness of individuals to environmental requirements (Hirzel et al., 2008). Ecological niche factor analysis, which is based on Hutchinson's definition of a niche, was used to explore suitability of the agriculturally dominated landscape of the NGP with its current arrangement of conservation program grasslands and wetlands for amphibians. The goal of habitat suitability modeling is to identify areas of habitat suitable for the persistence of a species based on a set of variables describing environmental conditions (Franklin, 1995; Guisan and Zimmermann, 2000; Hirzel and Le Lay, 2008).

\section{MATERIALS AND METHODS}

Study site.-We conducted our study within a $196 \mathrm{~km}^{2}$ study area in Stutsman County, east-central North Dakota (Fig. 1). The climate of east-central North Dakota within the NGP consists of long, cold, dry winters and short, mild, variably wet summers (Rosenberry, 2004). January temperatures

\footnotetext{
${ }^{1}$ U.S. Geological Survey, Northern Prairie Wildlife Research Center, Jamestown, North Dakota 58401; E-mail: (DMM) dmushet@usgs.gov. Send reprint requests to DMM.

${ }^{2}$ Department of Biological Sciences, and Environmental and Conservation Science Program, North Dakota State University, Fargo, North Dakota 58105; E-mail: (CAS) craig.stockwell@ndsu.edu. 


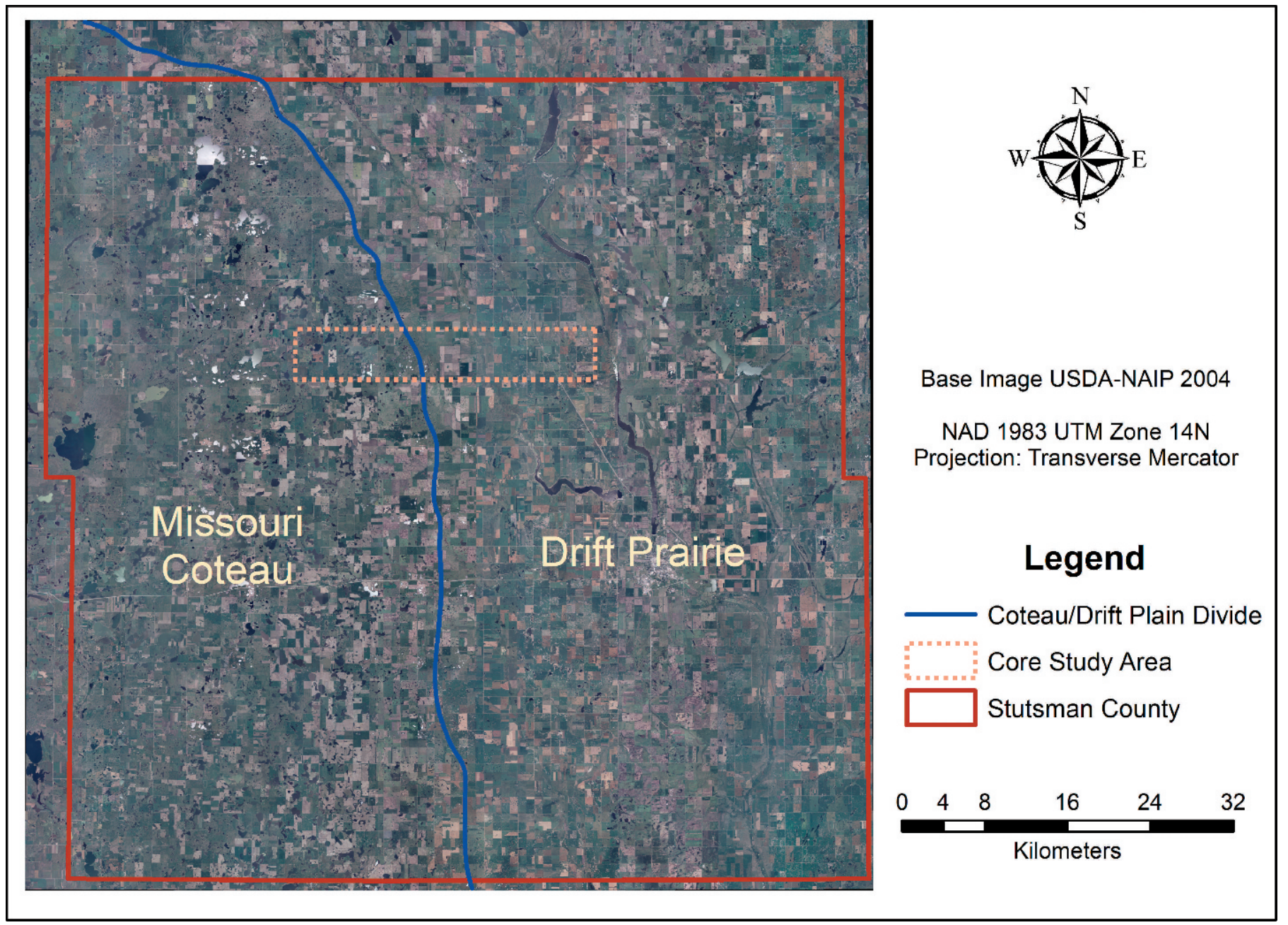

Fig. 1. Stutsman County, North Dakota and location of $196 \mathrm{~km}^{2}(6.4 \times 30.6 \mathrm{~km})$ study plot.

average $-13.5^{\circ} \mathrm{C}$ and winters typically consist of 195 days with temperatures below $0^{\circ} \mathrm{C}$ (Rosenberry, 2004). Our study area was sized and shaped to contain a large number of wetland areas, to include areas representative of two dominant physiographic features, and to capture the diversity of land-use types typical of the region (Fig. 1). The western half of our study area consisted of a portion of glacial stagnation moraine known as the Missouri Coteau, which formed by the melting of ice blocks buried by thick superglacial drift, the subsequent collapse of the drift into resulting voids, and filling of the created depressions with runoff and groundwater. Innumerable prairie pothole wetlands exist within this poorly drained, collapsed, glacial topography. The eastern portion of our study area was primarily drift prairie where glaciers retreated at a fairly even rate, leaving behind an undulating plain of low-relief ground moraine. Wetlands in the drift prairie are less numerous and generally shallower than those in the stagnation moraine of the Missouri Coteau. Within this study area, we measured an array of landscape, geological, and environmental variables (ecogeographical variables) and used data from nighttime amphibian call surveys conducted during the summers of 2008 and 2009 to facilitate amphibian habitat suitability modeling.

Ecogeographical data.-We used low altitude aerial photography collected in August 2008 and visual surveys conducted from roads throughout the study area to create a GIS land-use layer of the study area (Fig. 2). Land-use features were manually digitized using ArcMap ${ }^{\circledR}$ version 9.3.1 to facilitate the creation of ecogeographical layers relevant to amphibian habitat suitability. Land-use categories identified included grassland, hayland, wetland, trees, farmsteads, roads, and croplands. Croplands were further identified by crop type which included soybeans, corn, sunflowers, canola, flax, and small grains. We then converted the land-use feature map to a raster map with an output cell size of $26 \times 26 \mathrm{~m}$ from which we could extract land-use types of interest.

The first land-use type we extracted was grasslands. The extracted layer was binary in nature with ones representing grassland areas and zeros representing non-grassland areas. Next, we created a raster layer of 1216 isometric cells, $402 \mathrm{~m}$ on a side to cover the entire study area. Each cell corresponded to a 16.2 ha (quarter of a quarter-section) parcel of land on the ground. Sections (259.2 ha, 640 acres), quarter-sections (64.8 ha, 160 acres), and quarter of a quarter-section (16.2 ha, 40 acres) are the dominant landuse units used within the region's croplands. We used the spatial analyst tool of ArcMap to assign to each 16.2 ha cell the percentage of grassland within that cell based on the percentage of $26 \times 26 \mathrm{~m}$ cells identified as grassland within the larger 16.2 ha cell (Fig. 3A). In a similar manner, we also created a 16.2 ha cell size raster layer of the wetland percentage within a cell (Fig. 3B). 

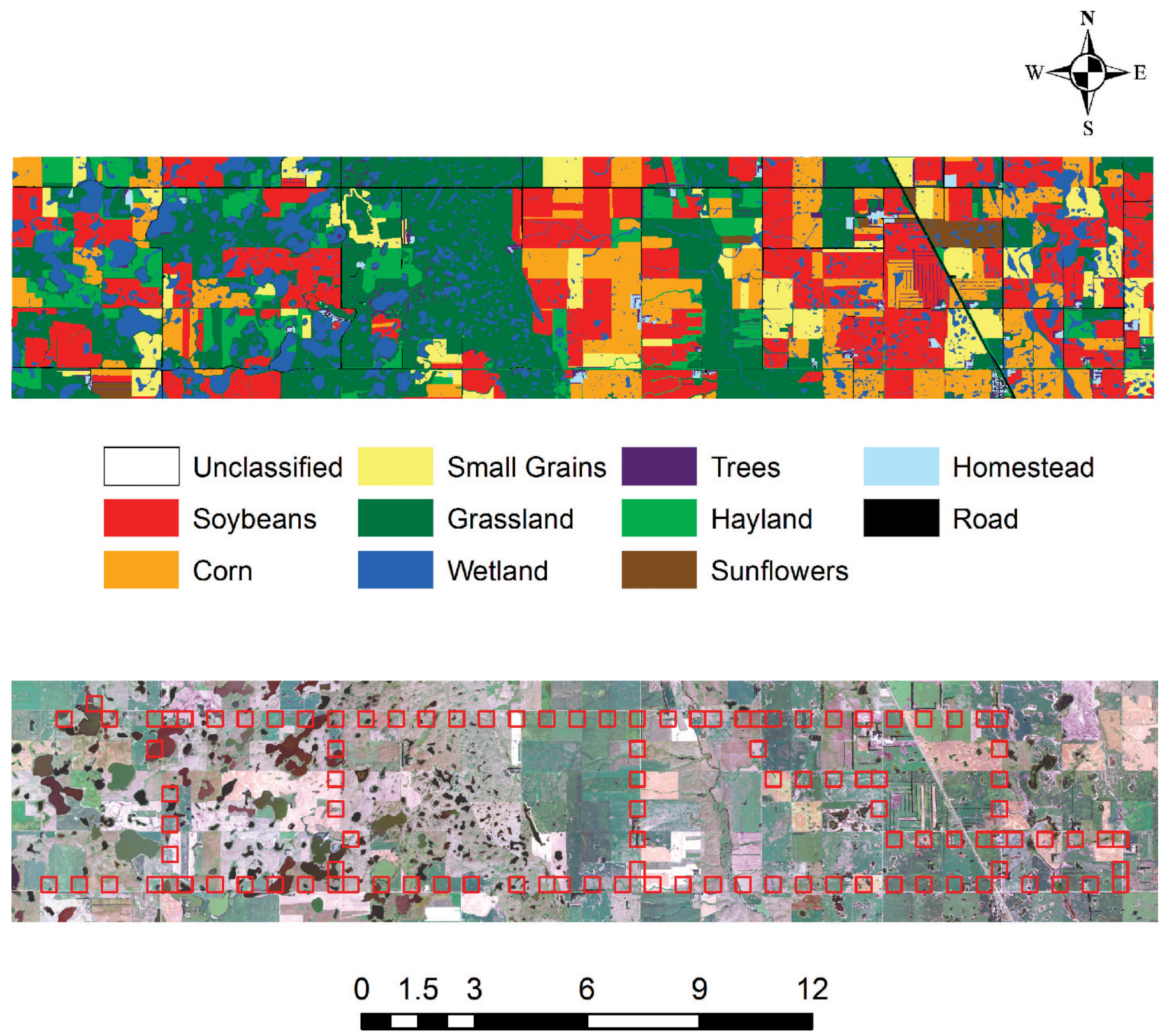

\section{Kilometers}

Fig. 2. Land-use and crop types within a $196 \mathrm{~km}^{2}(6.4 \times 30.6 \mathrm{~km})$ study area in Stutsman County, North Dakota, 2008. Red outlined cells in lower figure identify 110 cells within which nighttime amphibian call surveys were performed in 2008 and 2009.

We created a land-use index layer in which each of the ten land-use types identified in the original land-use map were ranked from zero to nine based on our best estimate of their value to amphibians. The rankings used were roads $=0$, corn $=1$, soybeans $=2$, sunflowers $=3$, small grains $=4$, homesteads $=5$, trees $=6$, hayland $=7$, grassland $=8$, and wetlands $=9$. For this layer, the value of each $26 \times 26 \mathrm{~m}$ cell was the cell's land-use index value. However, unlike the previous two layers, the values assigned to the 16.2 ha cells were the mean of all $26 \times 26 \mathrm{~m}$ cells occurring within each larger cell (Fig. 3C).

We also created raster layers for distance to trees (Fig. 4A), distance from a farmstead (Fig. 4B), distance to a breeding wetland (Fig. 4C), distance to an overwintering wetland (Fig. 5A), and distance to a Northern Leopard Frog (Lithobates pipiens) drought refugium (Fig. 5B). For these five layers, the value of each cell was the Euclidean distance from the cell's center to the nearest feature of interest. The distance to trees and distance to a farmstead layers were derived from the landuse feature map. For the distance from a breeding wetland layer we used National Wetlands Inventory (NWI) data from the U.S. Fish and Wildlife Service to identify breeding wetlands. We defined breeding wetlands to be NWI wetlands with a temporary or seasonal water regime (i.e., short hydroperiod wetlands). These wetlands are often small in size but are very important in maintaining amphibian populations (Gibbs, 2000). NWI data was also used to identify overwintering wetlands (i.e., wetlands with a semi-permanent or permanent water regime). These areas function as overwintering habitat for Northern Leopard Frogs and potentially are important to other species as well. We used satellite imagery from a drought year (1991) and Principal Component Analyses to identify Northern Leopard Frog drought refugia (see Mushet, 2010 for detailed methodology). 

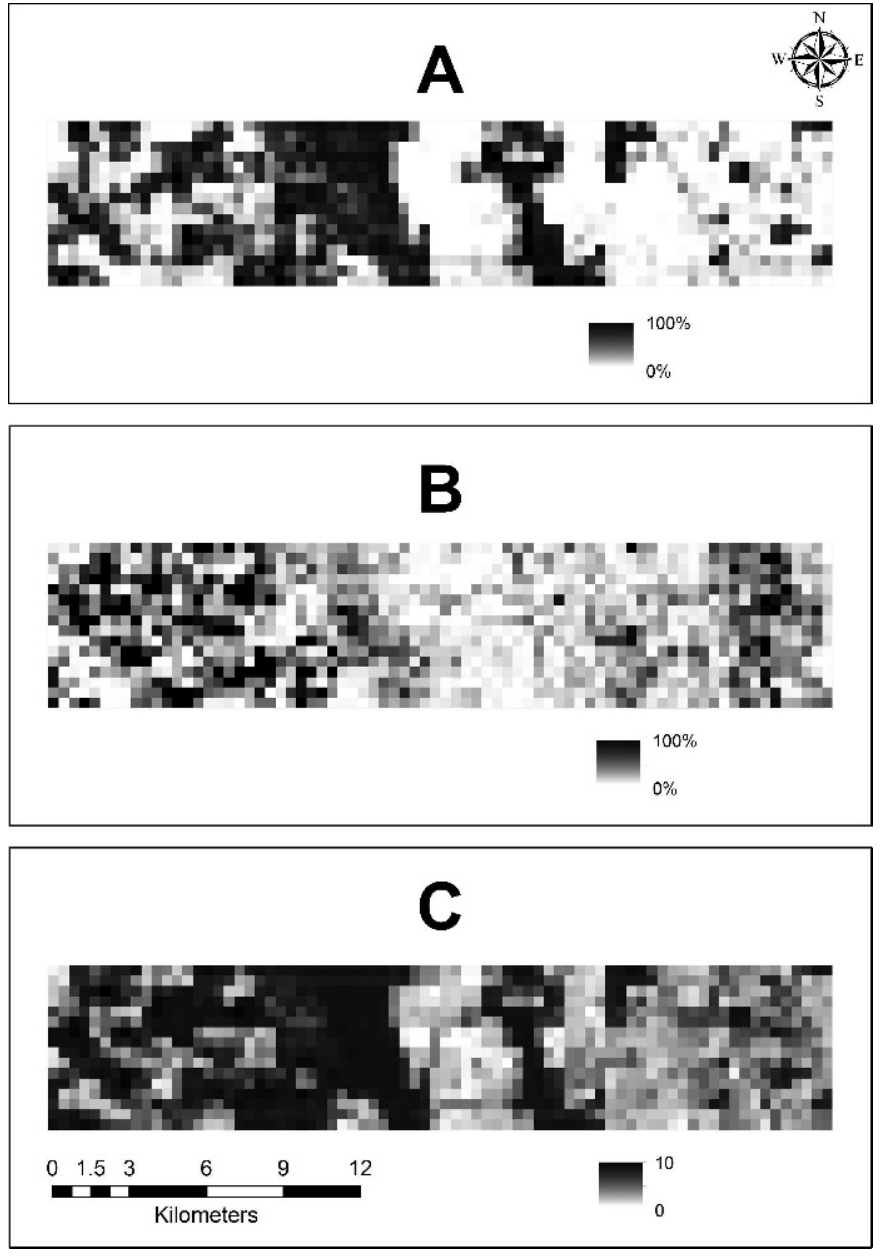

Fig. 3. Percent grassland (A), percent wetland (B), and land-use index (C) layers used in developing amphibian habitat suitability maps. Each pixel represents $402 \times 402 \mathrm{~m}$ (16.2 ha) on the ground.

Northern Leopard Frog drought refugia were defined as those semi-permanent or permanent wetlands that maintained sufficient water depth during periods of drought to support overwintering leopard frogs (Mushet, 2010).

The final ecogeographical layer we created (Fig. 5C) was designed to index soil permeability and thus the ability of amphibians that overwinter in uplands to avoid desiccation and freezing by burrowing. Soil permeability also affects vegetation and land-use, so this layer was utilized in all analyses, i.e., not just for burrowing species. The index we used was the percentage of sand in the c-horizon. These data were obtained from the U.S. Department of Agriculture's Soil Survey Geographic (SSURGO) Data Base (Natural Resources Conservation Service, 2010). The value of each 16.2 ha cell was the mean of all $26 \times 26 \mathrm{~m}$ cells within the larger cell. Tillage may also facilitate burrowing by making soils more friable. However, we did not create a separate layer for tillage as it was already accounted for by our percent grassland layer, i.e., the greater the amount of intact grassland in a cell, the lower the amount of tillage. In total, we created nine ecogeographical layers describing the environment of the study area, each with a cell size of 16.2 ha $(402 \times 402 \mathrm{~m})$.

Species occurrence data.-We used information from nighttime amphibian call surveys conducted in 2008 and 2009 to develop species occurrence data layers. Amphibian call
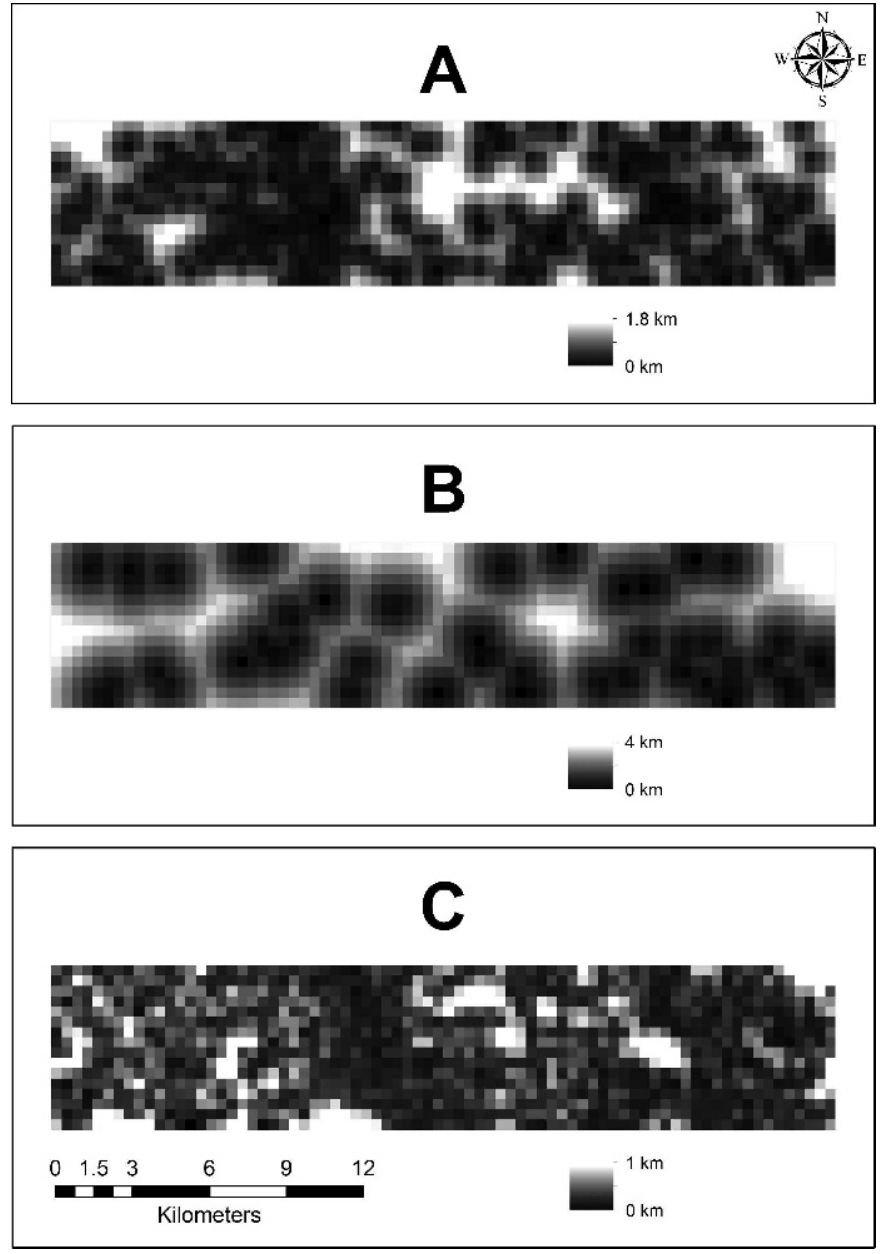

Fig. 4. Distance to trees (A), distance to farmstead (B), and distance to a breeding wetland $(C)$ layers used in developing amphibian habitat suitability maps. Each pixel represents $402 \times 402 \mathrm{~m}$ (16.2 ha) on the ground.

surveys were conducted once each week beginning in early April prior to the initiation of breeding activities and continuing through the end of July when most breeding activity had ended. Each survey was conducted by driving along established roads within the study area, stopping every $0.8 \mathrm{~km}(0.5 \mathrm{mi})$ at one of 110 systematically located survey points (Fig. 2). Survey points were located such that each was centrally located along the edge of one of the 1216 16.2 ha areas for which ecogeographical variables had been determined. Upon arriving at a survey point, surveyors waited for a two-minute pre-survey period prior to listening for calling anurans during a five-minute survey period. During the survey period, all amphibian species heard calling within the focal 16.2 ha sample site were recorded (Heyer et al., 1994). During surveys, a parabolic microphone was available to assist with directionally locating calling anurans to ensure that they were within the boundaries of the sample site. A digital recorder attached to the parabolic microphone was used to record calls for which species identifications were questionable. Surveyors then proceeded to the next survey point where the process was repeated. Air temperature, wind speed, cloud cover, and precipitation data were also recorded on pre-printed data sheets during each survey.

Each week, the starting point of the survey was randomly selected. Surveys were started each night $0.5 \mathrm{hrs}$ after sunset 

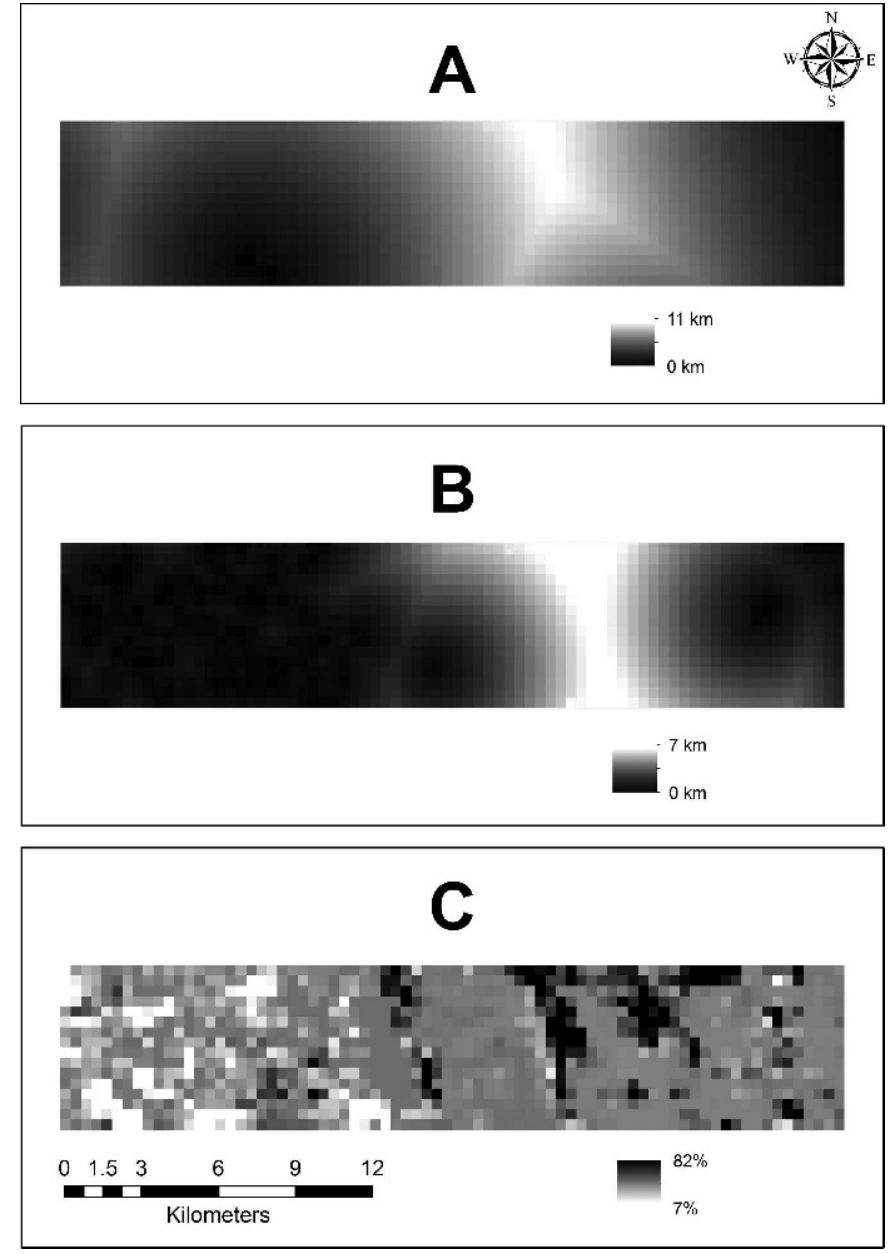

Fig. 5. Distance to an overwintering wetland (A), distance to a drought refugium (B), and percentage of sand in soil (C) layers used in developing amphibian habitat suitability maps. Each pixel represents $402 \times 402 \mathrm{~m}$ (16.2 ha) on the ground.

and continued for a $5 \mathrm{hr}$ period. Therefore, not all points could be sampled in a single night. Also, surveys were not conducted during rain events or when wind speeds were high enough to limit the ability of surveyors to hear calls ( $>18 \mathrm{mph},>4$ on the Beaufort wind scale). If conditions remained favorable throughout the survey period, all 110 sample sites could be surveyed in three nights. However, if a survey had to be cut short due to adverse environmental conditions, a fourth or sometimes fifth night was often required to survey all sites. Nightly surveys during a single survey week always began at the point where the previous night's survey ended. In total, each sample site was surveyed 14 times in 2008 and 15 times in 2009.

Data from the amphibian call surveys were used to derive species occurrence GIS layers. In order for a species to be counted as occurring within a 16.2 ha sample site, it had to have been counted in that site both of the two years of our study. By requiring a species to occur at a site for two consecutive years, we hoped to eliminate areas within which individuals occurred one year, but did not return the second year, indicating that reproduction in the first year was potentially not successful. The only exception to this was the Woodhouse's Toad (Anaxyrus woodhousii) which only occurred during one year of our study (2008). For this species, 2008 data was used in analyses and subsequent habitat suitability mapping.
Habitat suitability mapping.-We used BioMapper version 4.0 (Hirzel et al., 2008) to perform ecological niche factor analyses and to create habitat suitability maps for the five species encountered in our surveys following the procedures outlined in Hirzel et al. (2002). We used the AV 2 IDRISI extension for ArcGIS 9.x to convert all species occurrence and ecogeographical layers from an ArcGIS to an IDRISI format as required for use in Biomapper. Before analyses, all ecogeographical variables were normalized using the BoxCox algorithm and verified to guard against constant or nearly boolean maps (Hirzel, 2004). We then used Biomapper to create a covariance matrix and to perform ecological niche factor analyses for each species.

Ecological niche factor analysis is a multivariate approach useful for estimating species distributions without the need for absence data (Hirzel et al., 2002). In the factor analysis, a reference set of ecogeographical variables describing an area of interest is developed. Next, data from species distribution surveys are used to define a subset of the global set of ecogeographical variables within which the species is known to occur. The species defined subsets are compared to the global set within a factor analysis. The first factor extracted is the factor maximizing the distance between the species mean and the mean of the global set. This ecological distance between the optimum of the focal species and the mean of the environment is termed "marginality" as it defines how far away the optimum habitat of a species is from the mean habitat available globally within an area of interest. The absolute value of marginality ranges from zero to one. A value close to zero would indicate that the species lives in conditions that are average relative to the conditions of the entire study area. However, a value close to one indicates that the species lives in a rare habitat relative to what is available globally within the study area.

The other factors extracted maximize the species' "specialization," which is defined as the ratio of the variance of the mean habitat and that of the focal species. Each subsequent specialization factor explains a decreasing amount of variance in the data. Thus, along with the marginality factor, only a few specialization factors are typically needed to describe the majority of the information in a dataset. Specialization values range from 1 to infinity and are therefore difficult to interpret. However, an inverse transformation of specialization ( $1 / \mathrm{S})$ yields a "tolerance" value which like marginality ranges between zero and one. Tolerance values close to zero indicate a species that tends to be a specialist living within a narrow range of conditions. Species with tolerance values closer to one inhabit most any of the conditions present in the study area.

Our amphibian call surveys identified five species occurring within the study area; Northern Leopard Frogs, Wood Frogs (Lithobates sylvaticus), Boreal Chorus Frogs (Pseudacris maculata), Great Plains Toads (Anaxyrus cognatus), and Woodhouse's Toads. As previously noted, the Woodhouse's Toad occurred only during a single year of our study. Even so, we retained this species in our analyses using 2008 data. All ecogeographical variables were used in our ecological niche factor analyses except the Northern Leopard Frog drought refugia layer, which was only utilized for Northern Leopard Frogs. We then computed factor maps from the results of each factor analysis. Factor maps for the top three factors were weighted (Hirzel, 2004) based on the amount of variance described by each and used to create habitat suitability maps for each species. 
In the habitat suitability maps, cutoff values separating core, suitable, and unsuitable habitats for a particular species were selected so that $50 \%$ of the occurrence locations fell within core habitat, an additional $40 \%$ occurred in suitable habitat (i.e., core + suitable accounted for $90 \%$ of the occurrence locations), and the final $10 \%$ occurred in unsuitable habitat (Hirzel, 2004). The only exception was for the Boreal Chorus Frog. Due to its ubiquitous occurrence throughout our study area, we set suitable habitat to include $95 \%$ of the sample sites within which this species occurred and unsuitable habitat to include only $5 \%$ (rather than the $10 \%$ used for the other species).

\section{RESULTS}

Of the five amphibian species we detected in our study area, the Boreal Chorus Frog was most common, occurring in 95 of the 11016.2 ha sites sampled in 2008 and within all 110 sites sampled in 2009. Woodhouse's Toad was the rarest species, occurring in just 19 of 110 sample sites in 2008 and being completely absent from the sites sampled in 2009. Like Woodhouse's Toad, the number of 16.2 ha sample sites within which the Great Plains Toad occurred declined from 29 in 2008 to 22 in 2009. Northern Leopard Frogs and Wood Frogs occurred in 22 and 26 sample sites, respectively, in 2008. In 2009, environmental conditions were favorable for these two species which responded by greatly expanding the number of sites within which they occurred; in 2009, Northern Leopard Frogs occurred in 65 of the sites sampled and Wood Frogs in 74.

In 2008, both toad species occurred exclusively in the drift plain (eastern half of the study area), while Northern Leopard Frogs and Wood Frogs occurred primarily in the Missouri Coteau (western half of the study area). However, in 2009 Northern Leopard Frogs and Wood Frogs greatly increased their area of occupancy and were common in both the Missouri Coteau and the drift plain while the two toad species remained restricted to the drift plain, if they occurred at all. The Boreal Chorus Frog was found throughout the study area during both years.

For each species sampled, the first three factors (marginality and the first two specialization factors) explained the majority of the information in the data sets. For Northern Leopard Frogs, these three factors explained $89 \%$ of the information. Factor one (marginality) was weighted at 1.24, factor two (first specialization factor) was weighted at 0.44 , and factor three (second specialization factor) was weighted at 0.10 for this species. For the remaining species (i.e., Wood Frog, Boreal Chorus Frog, Great Plains Toad, and Woodhouse's Toad) the first three factors explained 83\%, 73\%, $89 \%$, and $89 \%$ of the information, respectively. Weightings for factors one through three were 1.18, 0.27, and 0.21, respectively, for Wood Frogs; 1.15, 0.17, and 0.15, respectively, for Boreal Chorus Frogs; 1.33, 0.30, and 0.13, respectively, for Great Plains Toads; and 1.34, 0.24, and 0.19 , respectively, for Woodhouse's Toads.

Habitat suitability maps varied by species (Fig. 6). Habitat suitability maps for the Northern Leopard Frog (Fig. 6A) and Wood Frog (Fig. 6B) revealed close ties between grassland areas and areas identified as core habitat. Areas identified as core habitat averaged $66.1 \%$ grassland (95\% Confidence Interval $=63.4-68.7 \%$ ) for Northern Leopard Frogs and $60.3 \%$ grassland $(95 \%$ Confidence Interval $=57.7-62.9 \%$ ) for Wood Frogs. The opposite pattern was found for both toad species. Core habitats for the Great Plains Toad
(Fig. 6C) and Woodhouse's Toad were predominantly linked to croplands. Areas identified as core habitat for the Great Plains Toad and Woodhouse's Toad averaged only $3.8 \%$ grassland $(95 \%$ Confidence Interval $=2.9-4.7 \%)$ and $11.3 \%$ grassland (95\% Confidence Interval $=8.6-14.0 \%$ ), respectively. Additionally, 134 of the 226 areas identified as core habitat for the Great Plains Toad and 165 of 339 areas identified as core habitat for the Woodhouse's Toad contained no grassland area. The Boreal Chorus Frog habitat suitability map (Fig. 6D) identified this species as a true habitat generalist, occurring throughout the study area in both grasslands and croplands where wetlands were present. Areas identified as core habitat for the Boreal Chorus Frog averaged $34.2 \%$ grassland $(95 \%$ Confidence Interval $=31.6-$ $36.7 \%$ ), closely matching the average percent grassland for the entire study area $(34.0 \%, 95 \%$ Confidence Interval $=$ 0.320-0.361).

Marginality and specialization results from our ecological niche factor analyses match our previous results. The Northern Leopard Frog, Great Plains Toad, and Woodhouse's Toad all had relatively high marginality values (0.721, 0.775, and 0.630, respectively), indicating that they lived in marginal habitats compared to what was globally available throughout the study area. By contrast, Boreal Chorus Frogs had a marginality value of only 0.275, indicating that they lived in fairly average conditions throughout the site. Wood Frogs also had a lower marginality value (0.403), although not as low as the ubiquitous Boreal Chorus Frogs. Boreal Chorus Frogs were also the least specialized of the species we encountered (tolerance value = 0.923), while Northern Leopard Frogs, Great Plains Toads, and Woodhouse's Toads were the most specialized (tolerance values $=0.477,0.466$, and 0.493 , respectively). As with marginality, Wood Frogs fell in between the other species in terms of specialization (tolerance value $=0.785$ ). The contribution of individual factors to overall marginality and specialization scores are provided in Tables 1 and 2, respectively.

\section{DISCUSSION}

Habitat suitability maps developed for the Northern Leopard Frog, Wood Frog, Boreal Chorus Frog, Great Plains Toad, and Woodhouse's Toad revealed different patterns of core and suitable habitats. Our most significant findings were 1) the influence of deep-water overwintering wetlands on suitable habitat for all species encountered except the Boreal Chorus Frog; 2) the lack of overlap between areas of core habitat for both the Northern Leopard Frog and Wood Frog compared to the core habitat for both toad species; and 3) the importance of conservation programs in providing grassland components of Northern Leopard Frog and Wood Frog habitats.

The great differences in habitat types suitable to anurans of the NGP highlight the need for ecosystem based conservation and management approaches (Christensen et al., 1996) that consider the habitat requirements of multiple species; a management plan focusing on just an individual species would likely have unintended consequences on other species in an area. An ecosystem based approach in which the entire area is considered as an interconnected system will likely be required to obtain conservation and management decisions that favor the widest possible set of species utilizing an area. 

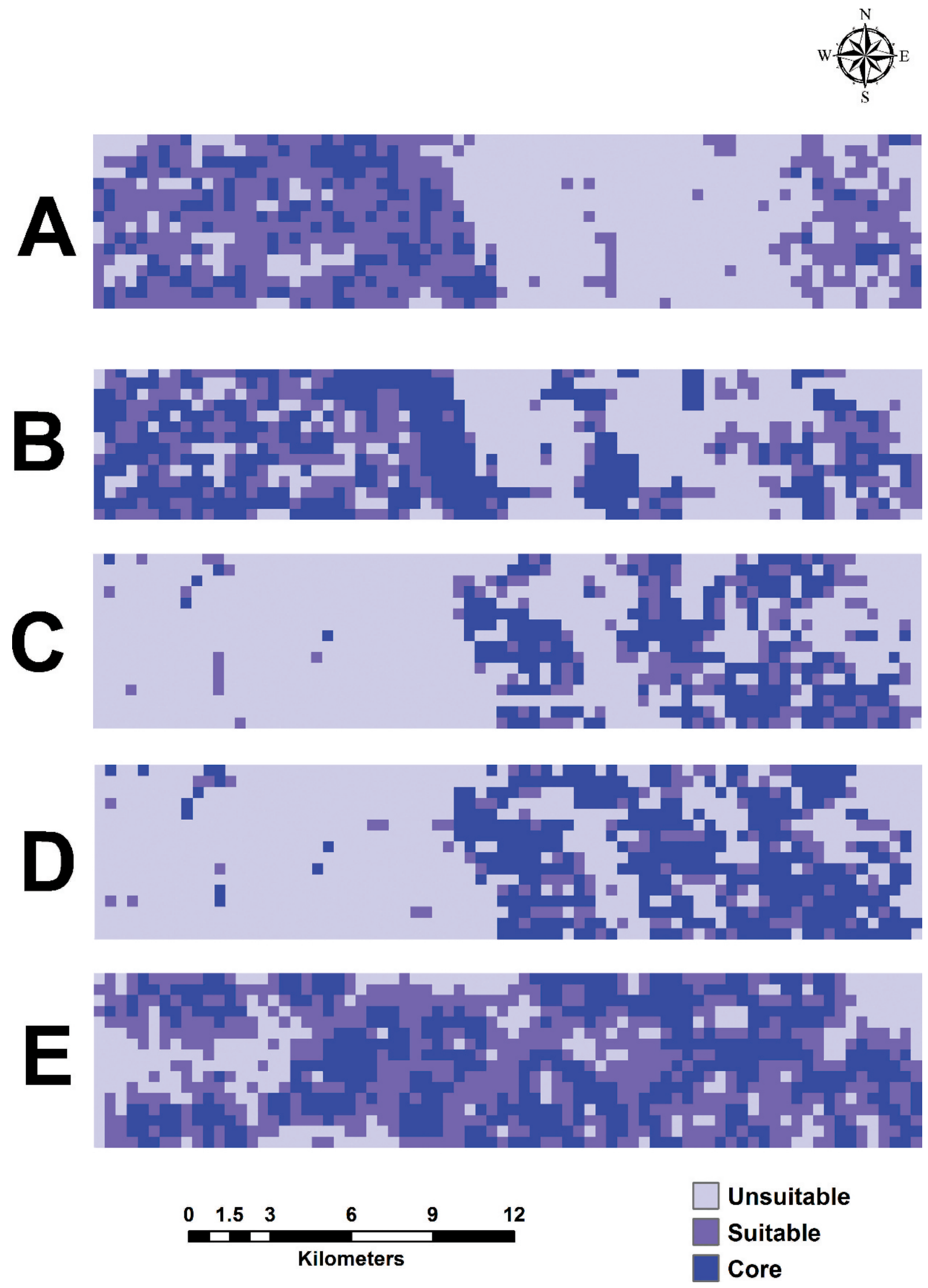

Fig. 6. Habitat suitability maps for (A) Northern Leopard Frog (Lithobates pipiens), (B) Wood Frog (Lithobates sylvaticus), (C) Great Plains Toad (Anaxyrus cognatus), (D) Woodhouse's Toad (Anaxyrus woodhousii), and (E) Boreal Chorus Frog (Pseudacris maculata) for a $196 \mathrm{~km}^{2}$ study area in Stutsman County, North Dakota. 
Table 1. Marginality Factor Scores for Northern Leopard Frog (NLF; Lithobates pipiens), Wood Frog (WF; Lithobates sylvaticus), Boreal Chorus Frog (BCF; Pseudacris maculata), Great Plains Toad (GPT; Anaxyrus cognatus), and Woodhouse's Toad (WHT; Anaxyrus woodhousii). The greater the absolute value of the coefficient, the more this variable contributed to a species' marginality factor. Values $\geq 0.40$ (in bold face) are considered strongly influential.

\begin{tabular}{lccrrr}
\hline Ecological variable & NLF & WF & BCF & GPT & WHT \\
\hline Percent grassland & 0.36 & 0.47 & -0.08 & -0.46 & -0.32 \\
Percent wetland & 0.38 & 0.17 & 0.10 & 0.07 & 0.00 \\
Land-use index & 0.39 & 0.49 & -0.11 & -0.39 & -0.23 \\
Distance from trees & -0.30 & -0.36 & -0.24 & 0.14 & 0.15 \\
Distance from farmstead & -0.14 & -0.36 & -0.84 & -0.30 & -0.34 \\
Percent sand in soils & -0.17 & -0.26 & 0.03 & 0.20 & 0.26 \\
Distance to breeding wetland & 0.01 & 0.04 & -0.34 & -0.48 & -0.46 \\
Distance to overwintering wetland & -0.57 & -0.43 & 0.32 & -0.50 & 0.65 \\
Distance to drought refugiuma & -0.36 & N/A & N/A & N/A & N/A \\
& & & & &
\end{tabular}

a Only used for Northern Leopard Frogs

An examination of individual factor scores contributing to overall marginality (Table 1) provides details relative to the relationships between suitable habitats and environmental variables. Suitable habitat for the Northern Leopard Frog was strongly influenced (i.e., factor coefficients were $\geq 0.40$ ) by the distance to an overwintering wetland. The distance to these longer hydroperiod, deep-water habitats also strongly influenced habitat suitability of Wood Frogs, Great Plains Toads, and Woodhouse's Toads. The negative coefficients for Northern Leopard Frogs, Wood Frogs, and Great Plains Toads indicated that the distances to deep-water overwintering wetlands for these species was less than what was globally available in the study area. However, the factor coefficient for Wood House's Toad was positive, indicating that suitable habitat for this species was farther away from these wetland types than the average distance across the sample area.

Deep-water overwintering wetlands are typically associated with Northern Leopard Frogs due to this species' need to overwinter underwater in wetlands that do not completely freeze. However, our analyses show that these wetlands are also important to other species that do not overwinter underwater. As noted, for some species the relationship is positive while for others it is negative. The importance of these longer hydroperiod wetlands to species that overwinter in the uplands may be due to the tendency of these sites to not be farmed, i.e., seasonal and temporary wetlands often dry early enough during the growing season to be farmed. Thus the longer hydroperiod wetlands may provide undisturbed habitat surrounding the watered area that is utilized by these anurans. Additionally, during dry years, the long hydroperiods of these wetlands are shortened and may mimic that of shorter hydroperiod temporary and seasonal wetlands typically utilized as breeding sites and identified as strongly influential for Great Plains Toads (Table 1). However, long hydroperiod wetlands can also support fish, Tiger Salamanders (Ambystoma tigrinum), and other predators that negatively influence species adapted to breed in short hydroperiod wetlands (e.g., Woodhouse's Toad). The Boreal Chorus Frog's lack of dependence on long hydroperiod, deep-water wetlands may contribute to their ability to occur across a broader area of the landscape than the other four species we encountered.

Surprisingly, we did not find a relationship between Northern Leopard Frogs and the distance to a drought refugium. It is well known that Northern Leopard Frogs are dependent on deep-water sites that persist through periods of drought (Lannoo, 2005; Mushet, 2010). However, the last severe drought within the area we sampled ended in 1993. Thus, in the intervening 15 years, Northern Leopard Frogs had ample time to redistribute themselves across the landscape, obscuring any patterns related to the locations of drought refugia. If our surveys were conducted in years during or immediately following drought, it is likely that

Table 2. Specialization Factor (SF) Scores (First Only) for Northern Leopard Frog (NLF; Lithobates pipiens), Wood Frog (WF; Lithobates sylvaticus), Boreal Chorus Frog (BCF; Pseudacris maculata), Great Plains Toad (GPT; Anaxyrus cognatus), and Woodhouse's Toad (WHT; Anaxyrus woodhousii). The greater the absolute value of the coefficient, the more this variable contributed to a species' marginality factor. Values $\geq 0.40$ (in bold face) are considered strongly influential.

\begin{tabular}{lcrrrr}
\hline Ecological variable & NLF & WF & BCF & GPT & WHT \\
\hline Percent grassland & -0.15 & -0.65 & -0.55 & 0.05 & -0.26 \\
Percent wetland & -0.10 & 0.50 & -0.03 & -0.55 & -0.13 \\
Land-use index & -0.24 & 0.70 & -0.58 & 0.69 & 0.52 \\
Distance from trees & -0.64 & -0.17 & 0.43 & 0.23 & -0.40 \\
Distance from farmstead & -0.44 & 0.18 & -0.26 & -0.17 & 0.55 \\
Percent sand in soils & 0.03 & -0.07 & 0.02 & 0.03 & -0.14 \\
Distance to breeding wetland & 0.21 & 0.03 & 0.17 & -0.14 & -0.16 \\
Distance to overwintering wetland & 0.50 & 0.13 & -0.26 & 0.35 & 0.38 \\
Distance to drought refugium $^{2}$ & -0.10 & N/A & N/A & N/A & N/A
\end{tabular}

${ }^{a}$ Only used for Northern Leopard Frogs 
this environmental variable would have emerged as being highly influential. Our inability to detect the importance of drought refugium wetlands during a period when overwintering sites were abundant across the landscape provides insight into pitfalls associated with studies conducted over short temporal periods (e.g., the two years of this study). Some important factors may not be apparent on a short temporal scale especially in highly dynamic habitats, increasing the difficulty in identifying and therefore preserving potentially critical components that may be influential only during rare but extremely important events such as drought.

Percent sand in soil was not an influential factor for any of the anurans we studied. Either this variable did not accurately represent the suitability of a soil for burrowing or other environmental variables were more influential, masking any effect of soil type. Distance to trees and the percent wetland within an area also were not identified as being highly influential (Table 1).

Habitat suitability maps (Fig. 6) and the influence of individual factors on overall marginality scores (Table 1) highlight the strong influence of grasslands on anuran species of the NGP. Interestingly, while the relationship between the amount of grassland in an area and that area's suitability as habitat for a species was positive for Northern Leopard Frogs and Wood Frogs, it was negative for Great Plains Toads and Woodhouse's Toads (Table 1). These findings provide useful insights into the value of conservation programs that restore grasslands surrounding wetlands in the NGP. Within our study area, 3950 ha $(63.3 \%)$ of the total grassland area was croplands that had been replanted to perennial cover (data from U.S. Geological Survey, 2010). By way of an example of the importance of these conservation grasslands to anuran populations, Northern Leopard Frog core habitat blocks include a series of small grassland blocks in the eastern portion of the study area (Fig. 6). These habitat blocks were the only core areas identified in the eastern third of our study area. All of these grassland blocks were former croplands that had been replanted to grassland cover due to monetary incentives provided by conservation programs. A 2009 resurvey of the land-use in this portion of the study area revealed that most of these grassland blocks were being returned to agricultural production as a result of high commodity prices (Euliss et al., 2010). Because these conservation grasslands were the only areas of core habitat for Northern Leopard Frogs in the eastern third of the study area, continued conversion of these conservation grasslands to croplands would effectively eliminate all Northern Leopard Frog core habitat in this portion of the study area. Currently, contracts on over 7.6 million ha of conservation grasslands within the United States are scheduled to expire between 2010 and 2013 in the Conservation Reserve Program (U.S. Department of Agriculture, 2010). Loss of these grasslands would eliminate a great portion of the Northern Leopard Frog's habitat in the NGP.

Another concern identified in our research was the great reliance of the Great Plains Toad and Woodhouse's Toad on wetlands embedded within croplands. Little is known about the water quality of these wetlands and potential effects on reproduction and population viability in these highly modified habitats. Thus, ecological niche theory and the development of habitat suitability maps for amphibian species can not only provide unique insights into how species utilize a given landscape based on environmental requirements, but also can be used to identify potential issues of concern where additional research efforts may be warranted.

Occurrence of all five species varied greatly by year. In 2009, summer conditions were cool and wet relative to 2008. Additionally, spring runoff in 2009 was significantly greater filling many wetlands on the drift plain to above normal levels. These conditions likely favored Northern Leopard Frogs and Wood Frogs as reflected by their expansion into several areas where they did not occur the previous year. By contrast, the two toad species (Great Plains Toad and Woodhouse's Toad) were negatively affected by the differing climate conditions. In general, toad species with their dry, leathery skin, are better adapted to dryer, warmer conditions than frogs (Duellman and Trueb, 1994). The reduction in Great Plains Toad occurrences and the total absence of the Woodhouse's Toad within our study area in 2009 potentially was linked to the cooler, wetter conditions that year favoring the frog species we encountered. Conversely, in warmer, dryer climate conditions, such as those predicted to occur in the region due to global climate change (IPPC; Schneider et al., 2007), it is possible that the toad species will be favored over Northern Leopard Frogs and Wood Frogs, and perhaps even the ubiquitous Boreal Chorus Frog may be negatively affected.

\section{ACKNOWLEDGMENTS}

We greatly appreciate the financial support we received for this effort from the U.S. Department of Agriculture's Natural Resources Conservation Service through their Conservation Effects Assessment Project (CEAP-Wetlands) and the Farm Service Agency's Economic and Policy Analysis Staff. We thank K. Gustafson and T. Veldkamp for assisting the primary author with amphibian call surveys in 2008 and K. McLean and C. Kraft for assisting with surveys in 2009. Use of brand names in this manuscript does not constitute nor imply endorsement by the United States Government.

\section{LITERATURE CITED}

Alford, R. A., P. M. Dixon, and J. H. K. Pechmann. 2001. Global amphibian population declines. Nature 414:449-500.

Chase, J. M., and M. A. Leibold. 2003. Ecological Niches: Linking Classical and Contemporary Approaches. The University of Chicago Press, Chicago.

Christensen, N. L., A. M. Bartuska, J. H. Brown, S. Carpenter, C. D'Antonio, R. Francis, J. F. Franklin, J. A. MacMahon, R. F. Noss, D. J. Parsons, C. H. Peterson, M. G. Turner, and R. G. Woodmansee. 1996. The report of the Ecological Society of America Committee on the Scientific Basis for Ecosystem Management. Ecological Applications 6:665-691.

Cowen, R. 1990. Vanishing amphibians: why they're croaking. Science News 137:116.

Duellman, W. E., and L. Trueb. 1994. Biology of Amphibians. John Hopkins University Press, Baltimore, Maryland.

Euliss, N. H., Jr., L. M. Smith, S. Liu, M. Feng, D. M. Mushet, R. Auch, and Y. Loveland. 2010. The need for simultaneous evaluation of ecosystem services and land use change. Environmental Science and Technology 44:7761-7763.

Franklin, J. 1995. Predictive vegetation mapping: geographic modeling of biospatial patterns in relation to environmental gradients. Progress in Physical Geography 19: 474-499. 
Gibbs, J. W. 2000. Wetland loss and biodiversity conservation. Conservation Biology 14:314-317.

Grinnell, J. 1917. Field tests of theories concerning distributional control. American Naturalist 51:115-128.

Guisan, A., and N. E. Zimmermann. 2000. Predictive habitat distribution models in ecology. Ecological Modelling 135:147-186.

Halliday, T. 2000. Do frogs make good canaries? Biologist 47:143-146.

Heyer, W. R., M. A. Donnelly, R. W. McDiarmid, L. C. Hayek, and M. S. Foster. 1994. Measuring and Monitoring Biological Diversity: Standard Methods for Amphibians. Smithsonian Institution Press, Washington, D.C.

Hirzel, A. H. 2004. BioMapper 3 User's Manual. http:// www2.unil.ch/biomapper/Biomapper3-Manual.pdf (Accessed 12 January 2010).

Hirzel, A. H., V. Braunisch, G. Le Lay, J. Hausser, and N. Perrin. 2008. Biomapper 4.0. Laboratory of Conservation Biology, Department of Ecology and Evolution, University of Lausanne, Lausanne, Switzerland. Available from http://www.unil.ch/biomapper

Hirzel, A. H., J. Hausser, D. Chessel, and N. Perrin. 2002. Ecological-niche factor analysis: how to compute habitatsuitability maps without absence data? Ecology 83: 2027-2036.

Hirzel, A. H., and G. Le Lay. 2008. Habitat suitability modelling and niche theory. Journal of Applied Ecology 45:1372-1381.

Houlahan, J. E., C. S. Finlay, B. R. Schmidt, A. H. Meyer, and S. L. Kuzmin. 2000. Quantitative evidence for global amphibian population declines. Nature 404:752-755.

Hutchinson, G. E. 1957. Concluding remarks. Cold Spring Harbor Symposia on Quantitative Biology 22:415-427.

Kerby, J. L., K. L. Richards-Hrdlicka, A. Storfer, and D. K. Skelly. 2010. An examination of amphibian sensitivity to environmental contaminants: Are amphibians poor canaries? Ecology Letters 13:60-67.

Knutson, M. G., J. R. Sauer, D. A. Olsen, M. J. Mossman, L. M. Hemesath, and M. J. Lannoo. 1999. Effects of landscape composition and wetland fragmentation on frog and toad abundance and species richness in Iowa and Wisconsin, USA. Conservation Biology 13:1437-1446.

Lannoo, M. J. 1998. Status and Conservation of Midwestern Amphibians. University of Iowa Press, Ames, Iowa.

Lannoo, M. J. 2005. Amphibian Declines: The Conservation Status of United States Species. University of California Press, Berkeley, California.

Lannoo, M. J., K. Lang, T. Waltz, and G. S. Phillips. 1994. An altered amphibian assemblage: Dickinson County,
Iowa, 70 years after Frank Blanchard's survey. American Midland Naturalist 131:311-319.

Larson, D. L., N. H. Euliss, Jr., M. J. Lannoo, and D. M. Mushet. 1998. Amphibians of northern grasslands, p. 450-451. In: Status and Trends of the Nation's Biological Resources. Volume 2. M. J. Mac, P. A. Opler, C. A. Puckett Haecker, and P. D. Doran (eds.). United States Department of the Interior, United States Geological Survey, Reston, Virginia.

Mushet, D. M. 2010. From earth-observing space satellites to nuclear microsatellites: amphibian conservation in the northern Great Plains. Unpubl. Ph.D. diss., North Dakota State University, Fargo, North Dakota.

Natural Resources Conservation Service. 2010. United States Department of Agriculture. Soil Survey Geographic (SSURGO) Database. Available online at http://soildatamart. nrcs.usda.gov (Accessed 14 January 2010).

Norris, S. 2007. Ghosts in our midst: coming to terms with amphibian extinctions. Bioscience 57:311-316.

Rosenberry, D. O. 2004. Climate of the Cottonwood Lake area, p. 25-34. In: Hydrological, Chemical, and Biological Characteristics of a Prairie Pothole Wetland Complex under Highly Variable Climate Conditions-The Cottonwood Lake area, east-central North Dakota. T. C. Winter (ed.). U.S. Geological Survey Professional Paper 1675, Washington, D.C.

Schneider, S. H., S. Semenov, A. Patwardhan, I. Burton, C. H. D. Magadza, M. Oppenheimer, A. B. Pittock, A. Rahman, J. B. Smith, A. Suarez, and F. Yamin. 2007. Assessing key vulnerabilities and the risk from climate change, p. 779-810. In: Climate Change 2007: Impacts, Adaptation and Vulnerability. Contribution of Working Group II to the Fourth Assessment Report of the Intergovernmental Panel on Climate Change. M. L. Parry, O. F. Canziani, J. P. Palutikof, P. J. van der Linden, and C. E. Hanson (eds.). Cambridge University Press, Cambridge, Massachusetts.

U.S. Department of Agriculture. 2011. Conservation Programs; Statistics; CRP Contract Expiration Schedule by State. http://www.fsa.usda.gov/FSA/webapp?area=home\& subject $=$ copr\&topic $=$ rns-css $($ Accessed 20 October 2011).

U.S. Geological Survey. 2010. National Biological Information Infrastructure, Gap Analysis Program (GAP). National Land Cover Version 1. http://www.nbii.gov/portal/server. pt/community/maps_and_data/1850 (Accessed 12 January 2010).

Wake, D. B., and H. J. Morowitz. 1991. Declining amphibian populations-a global phenomenon? Findings and recommendations. Alytes 9:33-42. 